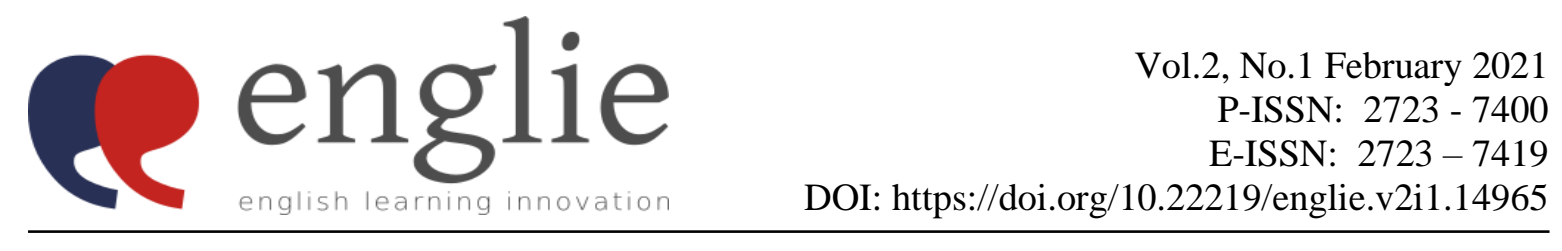

\title{
EFL Students' Perspectives on Their Self-efficacy in Speaking During Online Learning Process
}

\author{
Rista Ananda Ningias \\ Tidar University, Magelang, Indonesia \\ Corresponding Author: ristaananda2406@gmail.com
}

Lilia Indriani

Tidar University, Magelang, Indonesia

\begin{abstract}
This article illustrates the EFL students' perspectives toward self-efficacy of them in speaking during the online learning process. Self-efficacy defined as a person believes that he/she could manage the situation and get a positive outcome. It points out to the intuition in one's capacity to execute and organize the action required in producing the given attainments. Self-efficacy is very crucial for students in studying a language, especially for the fourth language skills. To achieve the qualification of English communication, mastering the fourth integrated skills is very necessary. Speaking includes in this term. The aim of this article was to analyze the EFL students' perspective about their selfefficacy in speaking during the online class activity. The research was conducted on 35 EFL learners of English Department Student at Tidar University. The researcher uses the descriptive quantitative method in analyzing the data. In obtaining them, the researcher employed a survey study by using a questionnaire with 20 close-ended questions. The result showed that the learners have enough selfefficacy in speaking during online learning. The high percentage of neutral option still dominate them. However, the final result of the data shows that learners have strong self-efficacy.
\end{abstract}

Keywords: EFL Student, Online Learning, Speaking, Self-efficacy

\section{INTRODUCTION}

The term self-efficacy alludes to an individual acceptance in one's capacity to coordinate and execute game-plans needed to achieve assigned kinds of performances (Bandura, 1997). Self-efficacy in training is identified with seeing self-adequacy in scholastics. It is about someone's ability judgment to establish and execute actions to achieve the specified type of educational performance (Nuvitasari et al., 2018). It means that self-efficacy affects the student's performance in learning a language, especially for EFL students. In learning a language there are four main language skills: listening, speaking, reading, and writing (Aydogan, 2014). The four integrated skills must be mastered. Every skill has its difficulty. But for the students, all of the four skills are very important. They must do their best in performing the fourth of them. The competence to communicate in English can be achieved by mastering 4 language skills and one of which is speaking (Kamil, D., \& Mukminin, 2015). Self-efficacy is the key to make students' performance better especially in speaking. The students' speaking self-efficacy and their speaking performance are related (Alawiyah, 2018). Research about students' anxiety and self-efficacy while doing English monologue showed that both of them impact learners' speaking skills. It shows that some students may perceive stress and depression 
to speak in front of people and facing the task requirements (Fatimah, 2018), particularly in speaking skills. Speaking in a language is hard for particularly unknown dialect understudies that viable oral correspondence requires the capacity to utilize the language suitably in social collaboration (Shumin, 2002). Most EFL students feel extremely anxious when speaking English in front of many people. They are usually tongue-tied or lost for words. So, their speaking performance is very poor. Self-efficacy ought to be considered an element of this tension and depression (Tahmassian \& Moghadam, 2011). Therefore, self-efficacy assumes a significant part of speaking because it has the strength to reduce anxiety and negative thoughts.

In this pandemic situation, the education institutions conduct online learning as an alternative for still doing the teaching-learning process. The method of spread from people to people made the requirement for social separating and evasion of swarmed places. Considering this, most governments have closed down schools and organizations where groups can't stay away from until additional notification (Aboagye et al., 2020). The distance of internet learning has become the standard, and a few public and global scholastic social orders have consolidated assets to guarantee that proceeding with clinical instruction happens during this difficult time (Schneider \& Laurin, 2020). The school's virtual study hall techniques need to address staff and understudy concerns. Staff preparing and the foundation of compelling help structures for inserting protected, secure, and compensating virtual homerooms are required (Michael, 2012). E-learning conditions have the nature of empowering different correspondence advances that can be utilized on autonomous stages to be utilized together (Onal, N., \& Ibili, 2017). The use of video conference platforms such as Zoom and Google Meet allows students to do face-toface virtual meetings during this process. They do not need to go to campus or school but just stay at home. If individuals who utilize these environments have access to distance learning lesson content and possess the skills of time management and use of the relevant technologies, The positive effects to help the success of their academic can be created (Taipjutorus et al., 2012). In the normal classroom, they meet directly with their teachers or lecturers and their friends, but in online learning, they meet them virtually. This condition may affect the student's performance and of course their self-efficacy. The study of self-efficacy has been conducted between the late 1970s and the early 1990s before online learning has occurred (Hodges, 2008).

As discussed before that most EFL students feel anxious when they speak English in public. It becomes one of the stressful things because of their lack of self-efficacy. The use of virtual meetings will give a different atmosphere for students, so it may increase their selfefficacy. In 2017, Paradewari already has investigated students' self-efficacy. She investigated students' self-efficacy in public speaking class and the result showed that the students have a positive self-efficacy in speaking English. The difference between this research and the previous research is in the term of online learning. The students' performance during offline and online learning will be different, so the researcher tries to investigate the students' perspective about their self-efficacy in this online learning that involves English Department Students at Tidar University.

\section{METHOD}

This research utilized a descriptive quantitative approach. A quantitative research method manages to measure and investigating factors to get results. It includes the usage and examination of mathematical information utilizing explicit measurable methods to respond to questions like who, how much, what, where, when, the number of, and how (Apuke, 2017). The researcher used questionnaires to collect data about EFL students' perspectives on their 
self-efficacy in speaking during the online learning process. This study was taken from 33 students of the English Department in the first, third, and fifth semesters at Tidar University. (Cohen, 2007) explained that the questionnaire is a useful instrument and mostly used to collect survey information structured, mainly the numerical data that can be handled without the researcher's presence and relatively easy to analyze. A questionnaire is a device to get data from respondents. It is a productive method to gather information, the examiner should be sure of what is required and how to measure the factors of interest (Kazi, 2012). The questionnaires were distributed to them through online media. In this study, the respondents must answer 20 close-ended questions. (Leedy, P. D., \& Ormrod, 2005) emphasized that a close-ended question in the questionnaire gives restricted decisions to reply and uses basic, clear, and unambiguous language.

This research used a Likert scale to compute the EFL students' perspective on their selfefficacy. It was devised to measure 'attitude' in a scientifically accepted and validated manner (Joshi et al., 2015). (Salkind, 2012) in his original paper, discussed the infinite number of definable attitudes existing in a given person with the possibility of grouping them into "clusters" of responses. The construction of the Likert scale is unmoving into the aim of the analysis typically the research aims to know regarding the opinions/perceptions of participants connected with a single 'latent' variable (the phenomenon of interest). This 'latent' variable is expressed by many 'manifested' things within the form (Joshi et al., 2015). A Likert scale could be a psychological science scale that has multiple classes from that respondents prefer to indicate their opinions, attitudes, or feelings a couple of specific issues (Beglar \& Nemoto, 2014). Likert scale information was broken down at the stretch estimation scale. Likert scale things were made by computing a composite score (whole or mean) from at least four sort Likert-type things (Boone et al., 2012). The subject of the research showed their feeling toward statements given regarding every item on a bipolar scale such as "strongly agree, agree, undecided, disagree, and strongly disagree (Willits, F. K., Theodori, 2016). It was composed of 20 items based on a Likert scale ranging from one (strongly disagree) to five (strongly agree). The percentage is used in analyzing the result of the questionnaire. The researcher determined the participants' answers using the formula below (Akdon, 2007):

$$
\frac{\Sigma X}{N} \mathrm{X} 100 \%
$$

$\mathrm{X}$ : Sum of participants' answer for each statement

$\mathrm{N}$ : Number of participants

\section{FINDINGS AND DISCUSSION}

Table 1. The Result of The Questionnaire

\begin{tabular}{clcc}
\hline No & \multicolumn{1}{c}{ Statements } & Percentage & Desc. \\
\hline 1 & $\begin{array}{l}\text { I believe that I have enough ability to speak English in } \\
\text { front of my friends during my online class. }\end{array}$ & $66.3 \%$ & Strong \\
\hline 2 & $\begin{array}{l}\text { I motivate myself to enhance my speaking skill in the } \\
\text { online class. }\end{array}$ & $78.9 \%$ & Strong \\
\hline 3 & I can deliver an organized speech in the online class. & $63.4 \%$ & Strong \\
\hline 4 & $\begin{array}{l}\text { I can maintain my posture while delivering a speech } \\
\text { during the online class. }\end{array}$ & $62.2 \%$ & Strong \\
\hline
\end{tabular}




\begin{tabular}{|c|c|c|c|}
\hline 5 & $\begin{array}{l}\text { In the online class, I can explain the material of speech } \\
\text { clearly so that my friends understand what I say. }\end{array}$ & $61.7 \%$ & Strong \\
\hline 6 & I can deliver my speech confidently during online class & $65.1 \%$ & Strong \\
\hline 7 & $\begin{array}{l}\text { I push my effort to deliver my speech better during online } \\
\text { class }\end{array}$ & $76.6 \%$ & Strong \\
\hline 8 & $\begin{array}{l}\text { I can find some strategies for delivering my speech during } \\
\text { the online class. }\end{array}$ & $68 \%$ & Strong \\
\hline 9 & $\begin{array}{l}\text { I can get the benefits of using the strategies that I find in } \\
\text { delivering my speech. }\end{array}$ & $69.7 \%$ & Strong \\
\hline 10 & $\begin{array}{l}\text { I can maintain my speech during the time given in online } \\
\text { class }\end{array}$ & $65.7 \%$ & Strong \\
\hline 11 & $\begin{array}{l}\text { I can limit the content of my speech to two to four main } \\
\text { ideas. }\end{array}$ & $62.3 \%$ & Strong \\
\hline 12 & $\begin{array}{l}\text { My friends support me when I deliver my speech in the } \\
\text { online class. }\end{array}$ & $73.1 \%$ & Strong \\
\hline 13 & $\begin{array}{l}\text { My lecturer helps me to arrange an organized speech in the } \\
\text { online class }\end{array}$ & $68 \%$ & Strong \\
\hline 14 & $\begin{array}{l}\text { The atmosphere in my classroom motivates me to deliver } \\
\text { an organized speech better. }\end{array}$ & $70.9 \%$ & Strong \\
\hline 15 & I can raise or lower my voice to make my speech powerful. & $69.7 \%$ & Strong \\
\hline 16 & $\begin{array}{l}\text { I am a credible speaker during my speech because I can } \\
\text { deliver my speech clearly in the online class. }\end{array}$ & $59.4 \%$ & Average \\
\hline 17 & I have a role model for delivering the speech effectively. & $65.7 \%$ & Strong \\
\hline 18 & $\begin{array}{l}\text { I can use facial expressions during my speech in the online } \\
\text { class. }\end{array}$ & $63.4 \%$ & Strong \\
\hline 19 & I can use gestures during my speech in the online class. & $67.4 \%$ & Strong \\
\hline 20 & I feel relieved and delighted after delivering my speech. & $76.6 \%$ & Strong \\
\hline
\end{tabular}

Source: (Paradewari, 2017)

Descriptions:

$\begin{array}{ll}0 \%-20 \% & : \text { Very weak } \\ 21 \%-40 \% & : \text { Weak } \\ 41 \%-60 \% & : \text { Average } \\ 61 \%-80 \% & : \text { Strong } \\ 81 \%-100 \% & : \text { Very strong }\end{array}$

(Riduan \& Akdon, 2007)

Based on the data obtained, the students of the English Department at Tidar University aware of their self-efficacy. It is because the 35 participants gave a constructive response toward the statements given. The first five questions were about students' self-efficacy awareness in online speaking. The participants believe that they have enough ability to speak in front of their friends during an online class. After being calculated using the formula provided, the percentage reached $66.3 \%$. It is a strong result that demonstrates the participant has good self-efficacy in the first statement. In the term of motivating themselves to enhance their speaking, the result is $78.9 \%$. The percentage shows a higher number than before. It is categorized as a strong result. For the next statements in the term of delivering and organizing the speech, they have enough confidence to perform better. It can be seen from the percentage that reached $63.4 \%$. Although it is lower than the two statements before, it is still categorized as strong. They also have enough self-efficacy in maintaining their posture and give a clear explanation to their friends during online learning. The result showed the percentages are about $62.2 \%$ and $61.7 \%$. It is almost become average but still categorized as strong. In explaining the material clearly to create understanding for their friends about what they say, the percentage showed they have a strong awareness of their self-efficacy. It is about $61.7 \%$. 
Statements number 6 until number 14 showed us about students' self-efficacy in speaking during an online class. From the data obtained, the students feel confident in delivering their speech during online class with $65.1 \%$ that means strong. In the term of pushing their effort to better speech delivering, the percentage reached $76.6 \%$. This number belongs to the great number from this result. The participants showed $68 \%$ in finding the strategies in delivering their speech and get the benefits from them. The number showed $69.7 \%$. About maintaining their speech established on the time given and limit the content, each reached $65.7 \%$ and $62.3 \%$. They are still categorized as strong. For the next three statements, the result is still described as strong. They were about the friends' support and teachers' help, the atmosphere of the classroom that motivated them also becomes one of their parts. The percentages were about $73.1 \%, 68 \%$, and $70.9 \%$.

The next five statements described the factor influencing students' self-efficacy in the online learning process. There are the experience of mastery, the experience of vicarious, verbal or community persuasion, and emotional state (Bandura, 1997). The statements in the number 15 and 16 belong to mastery experience. The result showed that the students' perception of strong in raising or lowering their voice to make their speech powerful. Their belief in themselves as credible speakers showed the average result. It was about 59.4\%. It was under $60 \%$, so we can categorize it as average. They have a great perception of themselves as having a role model in effectively delivering their speech. The number showed $65.7 \%$. The numbers 18 and 19 showed us statements about verbal or social persuasion. They were about the use of facial expressions and gestures during their speech in online learning. The data obtained showed they reached $63.4 \%$ and $67.4 \%$. The percentage of the use of gesture is more than facial expression, but both are categorized as a strong result. The last statement was about their feeling after conveying their speech. The students believe that they feel reassured and charmed after delivering their speech. The result showed $76.6 \%$ which is categorized as strong.

From the data obtained, the result showed that the students have good self-efficacy in speaking during the online learning process. Most of the results had reached more than $60 \%$ that means strong. There was just one below $60 \%$ or on the average level. They have great confidence in delivering their speech. Although the data above none of them that reach $80 \%$, it is strong enough to be categorized as a positive response because from the list of description, we know that most of them belong to a strong result. So, the students of the English Department at Tidar University have good self-efficacy in speaking.

\section{CONCLUSION}

This research designs to report the students' perspectives towards self-efficacy they have during the online learning process. The data obtained show that students show positive responses and they have enough and positive speaking self-efficacy during online learning. The results reach the average of those positive responses. Almost of the percentage is more than $60 \%$. The students have their ability awareness, the organization, maintain their posture, and explain the clear material during the class. They also feel confident and applying some strategies in speaking during an online class. The atmosphere of the classroom also becomes one important point to motivate them in delivering their speech. The factor such as the experience of mastery, experience of vicarious, verbal or community persuasion, and emotional state (Bandura, 1997) become very influential in students' self-efficacy during the online learning process. From the data obtained, we can conclude that the learners have already had them. 


\section{REFERENCES}

Aboagye, E., Yawson, J. A., \& Appiah, K. N. (2020). COVID-19 and E-Learning: the challenges of students in tertiary institutions. 2(1), 1-8.

Akdon, R. (2007). Rumus dan data dalam analisis statistika. Penerbit Alfabeta.

Alawiyah, T. (2018). Speaking self-efficacy and EFL student teachers' speaking achievement. Edukasi: Jurnal Pendidikan Dan Pengajaran, 5(1), 87-96. https://doi.org/10.19109/ejpp.v5i1.2052

Apuke, O. D. (2017). Quantitative research methods : A synopsis approach. Kuwait Chapter of Arabian Journal of Business and Management Review, 6(11), 40-47. https://doi.org/10.12816/0040336

Aydogan, H. and A. A. A. (2014). The four basic language skills, whole language \& integrated skill approach in mainstream university classrooms in Turkey. Mediterranean Journal of Social Sciences, 5(9), 672-680.

Bandura, A. (1997). Self-Efficacy: The Exercise of Control. W. H. Freeman and Company.

Beglar, D., \& Nemoto, T. (2014). Developing Likert-scale questionnaires. JALT2013 Conference Proceedings, 1-8.

Boone, H. N., Boone, D. A., \& Virginia, W. (2012). Analyzing Likert Data Likert-Type Versus Likert Scales. 50(2).

Cohen, L. (2007). Research methods in education. In Research Methods in Education. https://doi.org/10.4324/9780203029053

Fatimah, S. (2018). The correlation between students' self-efficacy towards their spekaing skills at the Eleventh Grade students of MAN Salatiga in the academic year of 2018/2019. State Institute for Islamic Studies (IAIN) Salatiga.

Hodges, C. B. (2008). Self-efficacy in the context of online learning environments: A review of the literature and directions for research. Performance Improvement Quarterly, 20(34), 7-25. doi:10.1002/piq.20001

Joshi, A., Kale, S., Chandel, S., \& Pal, D. (2015). Likert scale: Explored and explained. British Journal of Applied Science \& Technology, 7(4), 396-403. https://doi.org/10.9734/bjast/2015/14975

Kamil, D., \& Mukminin, A. (2015). Indonesian students' multicultural awareness in homogeneously and heterogeneously populated schools and multicultural education policy. Asia-Pacific Collaborative Education Journal, 11(1), 29-41. https://repository.unja.ac.id/158/1/Indonesian Students' Multicultural Awareness.pdf

Kazi, A. M. (2012). Questionnaire designing and validation. Journal of the Pakistan Medical Association, 62(5), 514-516.

Leedy, P. D., \& Ormrod, E. J. (2005). Practical research: Planning and design. Pearson Education. 
Michael, K. (2012). Virtual classroom: reflections of online learning. Emerald Group Publishing Limited, 29(3), 156-165(10). https://doi.org/10.1108/10650741211243175

Nuvitasari, I., Rizka Safriyani, R., \& Rakhmawati, R. (2018). Students'self-efficacy in public speaking program At SMKN 1 Lamongan. 145, 244-250. https://doi.org/10.2991/iconelt17.2018.52

Onal, N., \& Ibili, E. (2017). (2017). E-ogrenme ortamlari [E-learning environment]. In S. Sahin \& C. Uluyol (Eds.), Egitimde Bilisim Teknolojileri [Information Technology in Education]. Pegem Akademi.

Paradewari, D. S. (2017). Investigating students' self-efficacy of public speaking. International Journal of Education and Research, 5(10), 97-108.

Riduan, \& Akdon. (2007). Rumus dan data dalam analisis statistika. Penerbit Alfabeta.

Salkind, N. (2012). "Technique for the Measurement of attitudes" Encyclopedia of Research Design. https://doi.org/10.4135/9781412961288.n454

Schneider, S. L., \& Laurin, M. (2020). Distance learning in the era of COVID - 19. Archives of Dermatological Research, 0123456789, 3-4. https://doi.org/10.1007/s00403-02002088-9

Shumin, K. (2002). Factors to consider: Developing adult EFL student speaking abilities. In J. C. Richards \& W. A. Renandya (Eds.). UK: Cambridge University Press.

Tahmassian, K., \& Moghadam, N. J. (2011). Relationship between self-efficacy and symptoms of anxiety, depression, worry and social avoidance in a normal sample of students. Iranian Journal of Psychiatry and Behavioral Sciences, 5(2), 91-98.

Taipjutorus, W., Hansen, S., \& Brown, M. (2012). Investigating a relationship between learner control and self-efficacy in an online learning environment. Journal of Open, Flexible and Distance Learning, 16(1), 56-69.

Willits, F. K., Theodori, G. L. \& L. (2016). Another look at Likert scales. Journal of Rural Social Sciences, 31(3), 126-139. http://journalofruralsocialsciences.org/pages/Articles/JRSS 2016 31/3/JRSS 2016313 126-139.pdf 